УДК 631.53:633.112.9

(C) 2015

Шевніков М. Я., доктор сільськогосподарських наук, професор,

Галич О. П., Лотиш І. І., Міленко О. Г., аспіранти

(науковий керівник - доктор сільськогосподарських наук, професор М. Я. Шевніков)

Полтавська державна аграрна академія

\title{
ДЕЯКІ ПАРАМЕТРИ ГОСПОДАРСЬКИ ЦІННИХ ОЗНАК СОРТУ СОЇ ДЛЯ УМОВ ЛІВОБЕРЕЖНОГО ЛІСОСТЕПУ УКРАЇНИ
}

\section{Рецензент - доктор сільськогосподарських наук, професор П. В. Писаренко}

\begin{abstract}
За результатами вивчення сортів сої виділені найбільш продуктивні сорти, які в умовах Лівобережного Лicocmenу поєднують короткий період вететаиії та основні компоненти продуктивності. Погодні умови вететаційного періоду суттєво впливали на тривалість міжфазних періодів. Урожайність насіння з однієї рослини залежала від висоти головного стебла, кількості плодоносних вузлів, бобів та насінин на рослині. У пізньостиглих сортів проявлявся негативний вплив висоти прикріплення нижніх бобів на насіннєву продуктивність.
\end{abstract}

Ключові слова: сорти сої, урожайність, господарськи иінні ознаки.

Постановка проблеми. Останнім часом в науковій літературі вказується на доцільність подальшого прогресу у підвищенні урожайності сільськогосподарських культур шляхом зниження частки емпіричної складової у сучасній селекційній практиці. Селекціонери вважають, що в цьому плані важливе значення мають тенденції зміни комплексу господарськи цінних ознак в процесі сортозміни. В селекційній роботі проходили значні зміни архітектоніки рослин сої. Співвідношення елементів структури врожаю на різних етапах селекційних робіт мали визначений характер. Від тривалості міжфазних періодів залежав ріст і розвиток сої. Високопродуктивні сорти сої мають фізіологічні особливості, які впливають на механізм перерозподілу пластичних речовин між органами рослин. У результаті аналізу експериментального матеріалу обгрунтовані параметри моделі сортів сої з потенціалом урожайності 4,5 т/га.

Аналіз основних досліджень і публікацій, у яких започатковано розв'язання проблеми. Сорти сої, які вирощуються в Україні, створені для різних грунтово-кліматичних зон і суттєво відрізняються один від одного за вимогами до факторів зовнішнього середовища та господарсько-цінними показниками. Зміна району вирощування по відношенню до місця створення сортів сої у більшості випадків негативно впливає на їх продуктивність $[1,2]$.

Тривалість вегетаційного періоду має важливе значення, бо цей показник впливає на продуктивність сої. Новостворені сорти повинні гарантувати достигання за оптимальних строків сівби та мінімальних енергетичних затратах для досушування насіння [3, 4].

За дослідженнями селекціонерів сорт потрібно розглядати як збалансовану систему прояву окремих показників та ознак, які тісно пов'язані між собою. Зменшення або збільшення одного 3 них призводить до суттєвої зміни інших показників. Загальна продуктивність рослин залежить від оптимального поєднання господарськоцінних ознак в одному сорті. Вивчення кореляційних зв'язків між умовами зовнішнього середовища та господарсько-цінними ознаками сої має практичне значення. Встановлений тісний зв'язок між висотою прикріплення нижніх бобів і загальною урожайністю сої, що в більшості випадків пов'язуємо зі втратами врожаю насіння під час збирання на високому зрізі. Дані свідчать про те, що чим більш пізньостиглий сорт, тим вплив висоти прикріплення нижніх бобів проявляється сильніше [5, 6].

Метою наших досліджень було агротехнічне оцінювання сортів сої для виявлення найбільш придатних для вирощування в умовах Лівобережного Лісостепу України.

У завдання досліджень входило вивчення господарськи цінних ознак сортів сої за різних умов вегетаційного періоду.

Методика проведення досліджень. Грунт дослідної ділянки - опідзолений чорнозем важкосуглинистого механічного складу. Об'ємна маса грунту коливається по горизонтах від 1,12

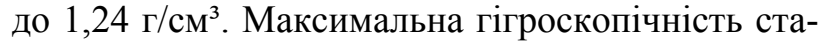
новить 11,6\%. Агрохімічні властивості грунту дослідної ділянки наступні (шар грунту 0-30 cм): гумус $-3,4-3,7 \%$, $\mathrm{pH}$ сольове $-5,8-6,0$, гідролітична кислотність - 5,2-5,5 мг/екв., вміст основних поживних речовин: легко гідролізного азоту (за Корнфілдом) - 14,8-16,5, фосфору $-8,8-10,3$, 


\section{СІЛЬСЬКЕ ГОСПОДАРСТВО. РОСЛИННИЦТВО}

калію - 16,7-19,0 мг на 100 грам грунту. Досліди закладали за 4-разового повторення з рендомізованим та стандартним розміщенням ділянок. Схеми дослідів складали, виходячи із завдань дослідження та стану вивчення даного питання. Для цього вивчали декілька типів сортів з різною тривалістю вегетаційного періоду. Спосіб посіву - широкорядний, 3 міжряддями 45 см. Усі варіанти досліду мали чотириразове повторення.

Результати досліджень. Продуктивність сільськогосподарських культур у регіоні залежить здебільшого від умов вологозабезпеченості, бо всі інші складові системи землеробства (видовий та сортовий підбір культур, обробіток грунту, система застосування добрив тощо) оцінюються, в першу чергу, з точки зору впливу їх на накопичення, збереження та економне використання вологи. 3 метою виявлення впливу окремих екологічних факторів на врожайність сої встановлено, що сума ефективних температур в умовах Лівобережного Лісостепу є цілком достатньою для вирощування ранньостиглих і середньостиглих сортів сої. Більш суттєвим фактором залишається нестійке та нерівномірне зволоження грунту протягом вегетаційного періоду.

Історичний досвід вказує, що селекція на посухостійкість $з$ метою підвищення продуктивності сої - завдання складне, а прогрес у цьому напрямі йде дуже повільно. Враховуючи велику мінливість умов зволоження в часі - в одні роки вирішальне значення має посухостійкість сорту, в інші - його потенційна продуктивність, стійкість до вилягання та хвороб. Такий перелік проблем у практичному впровадженні технології вирощування сої потребує вивчення впливу посухи як на окремі фізіологічні процеси, так і на ріст, розвиток і продуктивність рослин сої.

Для виявлення стресового фактора необхідне вирощування рослин в жорстко контрольованих умовах.

Але штучне моделювання стресових режимів суттєво відрізняється від польових умов. Для цього потрібні багаторічні польові дослідження 3 великою кількістю посушливих і сприятливих років, що спонукає до виявлення відповідного впливу вологозабезпечення грунту на основні показників продуктивності посівів сої в порівнянні зі зміною метеорологічних факторів і динаміки вмісту вологи в грунті. Значний ріст надземної маси більшості культур спостерігається за максимального використання сонячної енергіï, достатньому забезпеченні поживними речовинами та нормальному вологозабезпеченні. Тривала посуха у період вегетації сої спричиняє сут- тєві незворотні зміни - інтенсивно зменшується активна листкова поверхня, листки жовтіють i засихають. Зменшення площі фотосинтетичного апарату відповідно зменшує синтез органічної речовини.

Характеристика водного режиму визначається надходженням води у грунт та іï використанням, тобто водним балансом. Якщо формування врожаю вегетативної маси ранніх ярих культур в основному залежить від осінньо-зимових та весняних запасів вологи в грунті, то для формування врожаю сої вагоме значення мають атмосферні опади в період вегетації. Дослідники вказують на особливе значення характеру розподілу опадів протягом вегетаційного періоду: чим ближче цей розподіл до потреб у критичний період для рослин, тим продуктивніше буде використана вода для формування врожаю.

Погодні умови вегетаційного періоду суттєво впливали на тривалість міжфазних періодів. Сорти по-різному реагували на комплекс факторів зовнішнього середовища. Виділені відносно стабільні за даним показником сорти.

Основні елементи насіннєвої продуктивності, а також загальний урожай насіння в більшій мірі залежали від умов зовнішнього середовища. Урожайність насіння з однієї рослини залежала у більшій мірі від висоти головного стебла, кількості плодоносних вузлів, бобів та насінин на рослині. У пізньостиглих сортів проявлявся значний негативний вплив висоти прикріплення нижніх бобів на насіннєву продуктивність.

Сорт повинен мати наступні параметри господарськи цінних ознак:

- бути стійким до знижених температур у період проростання насіння та появи сходів;

- бути стійким до нестачі вологи у грунті, підвищеної температури та посушливих умов літнього періоду;

- мати високу інтенсивність росту i накопичення надземної маси на початку вегетаційного періоду 3 метою раціонального використання весняних запасів вологи і біологічного регулювання чисельності бур'янів;

- у період до повного цвітіння повністю сформувати фотосинтетичний та симбіотичний апарат і ці два взаємопов'язаних процеси повинні функціонувати тривалий період, що дасть можливість сповна забезпечити генеративні органи синтетичними речовинами та легкодоступними сполуками азоту;

- необхідно збільшити кількість продуктивних вузлів головного та бокових пагонів, долю тринасінних бобів та крупність насіння; 


\section{СІЛЬСЬКЕ ГОСПОДАРСТВО. РОСЛИННИЦТВО}

- скоротити розрив між показниками урожайності у різні за погодними умовами роки, зробивши сорти пластичними.

Сорти сої, створені для різних грунтовокліматичних зон, суттєво відрізняються один від одного за вимогами до факторів зовнішнього середовища та господарськи цінними показниками.

Зміна району вирощування у більшості випадків негативно впливає на їх продуктивність. Добір сортів сої для умов Лівобережного Лісостепу України потрібно проводити на основі багаторічних досліджень, бо умови зовнішнього середовища різних років здійснюють суттєвий вплив на цей показник.

У результаті вивчення великого добору сортів сої виділені найбільш продуктивні сорти Сінара, Ментор, Кент, Сігалія, які в умовах Лівобережного Лісостепу поєднують короткий період вегетації та основні компоненти продуктивності (табл. 1).

На основі вивчення господарськи цінних ознак районованих та перспективних сортів пропонуємо деякі практичні показники для моделювання сортів сої в умовах Лівобережного Лісостепу України (табл. 2).

Визначені показники продуктивності дають можливість раціонального використання грунтовокліматичних умов, забезпечують високу економічну ефективність вирощування.

Величина таких господарськи цінних ознак, як висота рослин, висота прикріплених нижніх бобів, кількість плодоносних вузлів, бобів і насінин на рослині, а також загальна маса насіння 3 однієї рослини, суттєво залежали від умов зовнішнього середовища.

У групі ранньостиглих сортів коливання висоти рослин становило від 64,1 до 73,5 см, середньоранніх - від 90,8 до 114,2 см, середньостиглих - від 64,1 до 118 см. Ще більший коефіцієнт мінливості цієї ознаки спостерігався у кількості плодоносних вузлів, бобів і насінин на одній рослині. Коефіцієнт мінливості цих ознак коливався від 15,5 до 43,0\%.

Вивчення кореляційних зв'язків між умовами зовнішнього середовища та господарськи цінними ознаками сої має практичне значення. Встановлений тісний зв'язок між висотою прикріплення нижніх бобів і загальною урожайністю сої, що в більшості випадків пов'язуємо зі втратами врожаю насіння у випадку збирання на високому зрізі. Дані свідчать про те, що чим більш пізньостиглий сорт, тим вплив висоти прикріплення нижніх бобів проявляється сильніше.
1. Урожсайність перспективних сортів сої в умовах Лівобережного Лісостепу Украӥни

\begin{tabular}{|c|c|}
\hline Сорт & $\begin{array}{c}\text { Урожайність, } \\
\text { т/га }\end{array}$ \\
\hline Кордоба & 2,55 \\
\hline Кардіф & 2,75 \\
\hline Лісабон & 2,75 \\
\hline Кент & 3,33 \\
\hline Мерлін & 2,35 \\
\hline Медісон & 2,55 \\
\hline Ларіса & 2,75 \\
\hline Діона & 2,16 \\
\hline Хуторянка & 2,55 \\
\hline Алігатор & 2,35 \\
\hline Ментор & 2,94 \\
\hline Султана & 2,75 \\
\hline Сінара & 3,14 \\
\hline Сігалія & 3,92 \\
\hline Медея & 1,57 \\
\hline НІР 0,5 & 0,08 \\
\hline
\end{tabular}

2. Рекомендовані параметри господарськи цінних ознак сорту сої, пристосованого до умов Лівобережного Лісостепу Украӥни

\begin{tabular}{|c|c|c|}
\hline $\begin{array}{c}\text { № } \\
\text { п/п }\end{array}$ & Ознаки, властивості & Показник \\
\hline 1 & Урожайність насіння, т/га & $2,5-3,0$ \\
\hline 2 & Висота рослин, см & $70-75$ \\
\hline 3 & $\begin{array}{c}\text { Кількість гілок на рослині, } \\
\text { шт. }\end{array}$ & $1,8-2,2$ \\
\hline 4 & $\begin{array}{c}\text { Кількість бобів на рослині, } \\
\text { шт. }\end{array}$ & $25-30$ \\
\hline 5 & $\begin{array}{c}\text { Кількість насінин } \\
\text { на рослині, шт. }\end{array}$ & $50-60$ \\
\hline 6 & $\begin{array}{c}\text { Кількість насінин у бобі, } \\
\text { шт. }\end{array}$ & $2,0-2,2$ \\
\hline 7 & Маса 1000 насінин, г & $160-180$ \\
\hline 8 & Тривалість вегетаціі, днів & $110-120$ \\
\hline 9 & $\begin{array}{c}\text { Висота прикріплення } \\
\text { нижніх бобів, см }\end{array}$ & $15-17$ \\
\hline 10 & Стійкість до вилягання & Висока \\
\hline 11 & Збиральний індекс, \% & $40-45$ \\
\hline 12 & Реакція на фотоперіодизм & Слабка \\
\hline 13 & Посухостійкість & Висока \\
\hline 14 & $\begin{array}{c}\text { Азотфіксуюча здатність, } \\
\text { мкг/рослину/год. }\end{array}$ & $20-30$ \\
\hline 15 & Тип росту & Напівдетер- \\
\hline 16 & Вміст у насінині, \% & $40-45$ \\
\hline & - жілка & $20-25$ \\
\hline
\end{tabular}


Висновок. У результаті вивчення великого вибору сортів сої виділені найбільш продуктивні сорти (Сігалія, Сінара, Діона, Кент), які в умовах Лівобережного Лісостепу поєднують короткий період вегетації та основні компоненти продуктивності. Погодні умови вегетаційного періоду суттєво впливали на тривалість міжфазних періодів. Сорти по-різному реагували на комплекс

\section{БІБЛІОГРАФІЯ}

1. Адамень Ф. Ф. Агроэкологическое обоснование сортовой структуры сои / Ф. Ф. Адамень : матеріали республіканської координаційнометодичної ради $з$ проблеми ефективного використання зрошуваних земель для вирощування $\mathrm{i}$ стабілізації виробництва кормів і кормового білка (Вінниця, 17-18 серпня 1994 року). - Вінниця : Інститут кормів УААН, 1994. - С. 42-43.

2. Бабич А. О., Бабич-Побережна А. А. Селекція і розміщення виробництва сої в Україні : монографія / А. О. Бабич, А. А. Бабич-Побережна. К. : ФОП Данилюк В. Г., 2008. - 216 с.

3. Наукові основи агропромислового виробництва в зоні Лісостепу України / [редколегія : факторів зовнішнього середовища. Урожайність насіння з однієї рослини залежала більшою мірою від висоти головного стебла, кількості плодоносних вузлів, бобів та насінин на рослині. У пізньостиглих сортів проявлявся значний негативний вплив висоти прикріплення нижніх бобів на насіннєву продуктивність.

Зубець М. В. (голова) та ін.]. - К. : Логос, 2004. $776 \mathrm{c}$.

4. Петр И. Формирование урожая сельскохозяйственных культур / И. Петр, В. Черны, Л. Грушка ; [пер. с болгарского яз. Благовещенской 3. К.]. - М. : Колос, 1984. - 367 с.

5. Петриченко В. Ф. Наукові основи сучасних технологій вирощування високобілкових культур / В. Ф. Петриченко, А. О. Бабич // Вісник аграрної науки. -2003 . - С. 15-19.

6. Шевніков М. Я. Світові агротехнології / Микола Янаєвич Шевніков. - Полтава : ВАТ «Видавництво Полтава», 2005. - 192 с. 